\title{
MODEL RESPONSIVITAS BIROKRASI DALAM IMPLEMENTASI KEBIJAKAN PELAYANAN KESEHATAN GRATIS DI KABUPATEN SIDENRENG RAPPANG
}

\author{
Basra \\ Kepala Puskesmas Empagae Kabupaten Sidenreng Rappang, Indonesia
}

\begin{abstract}
ABSTRAK
Tujuan penelitian ini adalah untuk menganalisis lebih jelas tentang proposisi dan alternatif model responsivitas birokrasi dalam implementasi kebijakan pelayanan kesehatan gratis di Kabupaten Sidenreng Rappang. Metode penelitian yaitu jenis penelitian kualitatif dengan pendekatan fenomenologi. Instrumen utama dalam penelitian ini adalah peneliti sendiri, didukung oleh instrumen penelitian lain seperti: pedoman observasi, pedoman wawancara, dan catatan dokumen. Teknik analisa data dengan menggunakan teknik analisis deskriptif dan proses analisa data dengan model interaktif dari Miles and Huberman dengan langkah-langkah sebagai berikut: 1) data condensation 2) data display, dan 3) data conclution drawing/verification. Hasil penelitian ini menunjukkan bahwa proposisi dan alternatif model responsivitas birokrasi dalam implementasi kebijakan pelayanan kesehatan gratis di Kabupaten Sidenreng Rappang dengan melalui beberapa dimensi yang menjadi pengembangan indikator responsivitas pelayanan publik, yaitu keramahan, kebersihan, kerjasama dan, kedisiplinan aparat birokrasi dalam merespon keluhan masyarakat dengan pelaksanaan kegiatan yang responsif.
\end{abstract}

Kata Kunci: Responsivitas, Birokrasi, Implementasi Kebijakan.

\section{PENDAHULUAN}

Responsiviness adalah salah satu dimensi pelayanan public yang penting, indikator pelayanan berkaitan dengan daya tanggap aparatur terhadap keluhan dan kebutuhan masyarakat yang membutuhkan pelayanan sebagaimana diatur di dalam peraturan. Rendahnya kemampuan birokrasi merespons dapat menimbulkan krisis kepercayaan terhadap birokrasi. Inisiatif dan kreativitas birokrasi dalam merespons krisis dan dampaknya sama sekali tidak memadai. Masyarakat yang mengharapkan birokrasi untuk memberi respons yang tepat dan cepat terhadap krisis yang terjadi menjadi amat kecewa karena ternyata tindakan birokrasi cenderung reaktif dan tidak efektif. Berbagai persoalan yang terjadi di pusat dan di daerah tidak dapat diselesaikan dengan baik, bahkan cenderung dibiarkan sehingga masyarakat menjadi semakin tidak percaya terhadap kemampuan birokrasi dalam menyelesaikan krisis ini.

Dari beberapa fenomena di atas menunjukkan betapa rapuhnya kepercayaan dan legitimasi pemerintah dan birokrasinya di mata masyarakat. Ini semua terjadi sebab pemerintah dan birokrasinya telah gagal menempatkan dirinya menjadi institusi yang bisa melindungi dan memperjuangkan kepentingan dan kebutuhan masyarakat. Orientasi kepada kekuasaan membuat birokrasi menjadi semakin tidak responsif dan tidak sensitif terhadap kepentingan masyarakatnya. Dominasi birokrasi dalam kehidupan politik dan ekonomi selama ini ternyata 
64| Ad'ministrare, Vol. 2 No. 2, Juli - Desember 2015

juga menciptakan berbagai distorsi dalam penyelenggaraan pelayanan masyarakat yang cenderung memperburuk krisis ekonomi dan politik yang terjadi.

\section{KAJIAN TEORI}

Birokrasi secara etimiologi berarti "kekuasaan di belakang meja". menurut Lance Castle adalah "orang-orang digaji yang berfungsi dalam pemerintahan". Birokrat brengsek, sebuah kalimat pendek bermakna jahat yang diungkap Blau dan Meyer, (2000:3) istilah "birokrasi" yang digunakan Blau dan Meyer ini bukanlah julukan yang mengacu pada inefisiensi dan inefektifitas pemerintahan, karena menurutnya itu bukanlah makna "birokrasi" yang sesungguhnya.

Blau (2000:6), istilah birokrasi digunakan sebagai sinonim inefisiensi, padahal Birokrasi merupakan suatu lembaga yang sangat kuat dengan kemampuan meningkatkan kapasitas potensial terhadap hal-hal yang baik dan buruk, karena birokrasi merupakan instrument administrasi rasional yang netral pada skala besar. Birokrasi mempermudah ekspansi imperialistis dan eksplotasi ekonomi sehingga merusak bangsa-bangsa terbelakang dan orangorang termiskin.

Birokrasi dimaksudkan sebagai satu sistem otoritas yang ditetapkan secara rasional oleh berbagai peraturan. Birokrasi menurut Widodo (2002), mempunyai peran penting dalam penyelenggaraan pemerintahan dan pembangunan. Dalam hubungan itu, peran birokrasi dapat dibedakan dalam tiga macam yaitu sebagai birokrat, politik dan profesi. Birokrasi sebagai profesi, menunjuk pada suatu okupasi tertentu yang menuntut adanya persyaratan khusus layaknya profesi lain, artinya jabatan birokrasi hanya bisa diisi oleh mereka yang mempunyai keahlian di bidang tertentu. (Rakhmat, 2009:68-69). Birokrasi pelayanan adalah organisasi yang pada hakikatnya merupakan bagian yang langsung berhubungan dengan masyarakat. Sejalan dengan kategori birokrasi pelayanan, Thoha (2003:78) mengatakan bahwa pelayanan yang diberikan oleh birokrasi pemerintah itu mempunyai monopoli untuk mempergunakan wewenang dan kekuasaan yang ada padanya untuk memaksa setiap warga negara mematuhi peraturan yang telah ditetapkan.

Dilulio (1994), menekankan bahwa responsivitas sangat diperlukan dalam pelayanan publik karena hal tersebut merupakan bukti kemampuan organisasi untuk mengenali kebutuhan masyarakat, menyusun agenda dan prioritas pelayanan serta mengembangkan program-program pelayanan publik sesuai dengan kebutuhan dan aspirasi masyarakat. Selanjutnya, dalam studinya tentang reformasi birokrasi di Indonesia, Dwiyanto (2008: 50-51), menjelaskan bahwa responsivitas adalah kemampuan organisasi untuk mengenali kebutuhan masyarakat, menyusun agenda dan perioritas pelayanan, dan mengembangkan program-program pelayanan publik sesuai dengan kebutuhan dan aspirasi masyarakat. Secara singkat responsivitas di sini menunjuk pada keselarasan antara program dan kegiatan pelayanan dengan kebutuhan dan aspirasi masyarakat.

Dwiyanto (2008:51) menyatakan bahwa responsivitas dimasukkan sebagai salah satu indikator kinerja pelayanan publik, karena responsivitas secara langsung menggambarkan kemampuan organisasi publik dalam menjalankan misi dan tujuannya, terutama untuk 
Basra, Model Responsivitas Birokrasi dalam Implementasi Kebijakan pelayanan kesehatan gratis $\mid 65$

memenuhi kebutuhan masyarakat. Responsivitas yang rendah ditunjukkan dengan ketidakselarasan antara pelayanan dengan kebutuhan masyarakat. Hal tersebut, menunjukkan kegagalan organisasi dalam mewujudkan misinya dan tujuan organisasi publik. Organisasi yang memiliki responsivitas rendah dengan sendirinya memiliki kinerja yang jelek pula.

Dwiyanto $(2008 ; 63)$ lebih lanjut di dalam operasionalisasinya mengembangkan beberapa indikator responsivitas pelayanan publik, yaitu : keluhan pengguna jasa, sikap aparat birokrasi dalam merespon keluhan pengguna jasa, penggunaan keluhan pengguna jasa sebagai referensi perbaikan layanan publik, berbagai tindakan aparat birokrasi dalam memberikan pelayanan, dan penempatan pengguna jasa oleh aparat birokrasi dalam sistem pelayanan yang berlaku. Keluhan pengguna jasa merupakan indikator pelayanan yang memperlihatkan bahwa produk pelayanan yang selama ini dihasilkan oleh birokrasi belum dapat memenuhi harapan pengguna layanan.

\section{METODE PENELITIAN}

Jenis penelitian ini adalah penelitian deskriptif kualitatif. Penelitian ini menganalisis model responsivitas birokrasi dalam implementasi kebijakan pelayanan kesehatan gratis di Kabupaten Sidenreng Rappang. Sumber data dalam penelitian ini adalah aparat birokrasi dan masyarakat pengguna jasa (stakeholders) yang memiliki pengalaman dan pengetahuan tentang kondisi kesehatan di Kabupaten Sidenreng Rappang, sesuai dengan tugas pokok dan fungsi masing-masing, yang terdiri dari: (1) Data primer diperoleh dari sejumlah data yang dijaring dari informan berdasarkan keterangan, pernyataan, dan informasi yang diperoleh secara sengaja yang berkenaan dengan fokus penelitian melalui observasi dan wawancara. Informan terdiri dari Kepala Dinas Kesehatan, Kepala Puskesmas, Tenaga medis dan Keperawatan, Staf Dinas Kesehatan, Tokoh Masyarakat dan Lembaga Swadaya Masyarakat; (2) Sumber data sekunder meliputi data dan dokumentasi yang relevan dengan fokus penelitian berupa dokumen tertulis (peraturan daerah, buku literatur, karya ilmiah, jurnal nasional dan internasional, laporan media massa maupun media elektronik/internet, rencana induk pengembangan, rencana strategis, dan rencana tahunan), gambar-gambar, maupun data statistik yang menjelaskan perkembangan pelayanan publik di bidang kesehatan. Instrumen utama dalam penelitian ini adalah peneliti sendiri, didukung oleh instrumen penelitian lain seperti; pedoman observasi, pedoman wawancara, dan catatan dokumen.

\section{HASIL PENELITIAN DAN PEMBAHASAN}

\section{Model Responsivitas Birokrasi dalam Implementasi Kebijakan Pelayanan Kesehatan gratis}

Berbagai upaya yang dilakukan oleh aparat birokrasi dinas kesehatan Kabupaten Sidenreng Rappang dalam memenuhi harapan, keinginan, aspirasi, maupun tuntutan masyarakat terhadap beberapa keluhan-keluhan yang muncul dalam implementasi kebijakan pelayanan kesehatan gratis di Kabupaten Sidenreng Rappang. Besarnya harapan dan keinginan masyarakat 
pengguna jasa dalam menerima layanan kesehatan di berbagai tingkatan pelayanan kesehatan yang ada, baik di Puskesmas Pembantu, Pos Persalinan Desa, Puskesmas, maupun di Rumah Sakit pemerintah, sehingga aparat birokrasi harus memberikan pelayanan yang profesional dan berkualitas.

Bentuk responsivitas yang dilakukan oleh aparat birokrasi dinas kesehatan Kabupaten Sidenreng Rappang dalam menangani keluhan masyarakat pengguna jasa terhadap implementasi kebijakan pelayanan kesehatan gratis, sebagaimana diutarakan oleh beberapa informan dalam penelusuran wawancara mendalam kepada orang yang dianggap lebih mengetahui program tersebut. Pernyataan informan tersebut memberikan indikasi bahwa bentuk responsivitas aparat birokrasi merupakan langkah yang positif dalam melaksanakan program pelayanan kesehatan gratis, sehingga kalau aparat birokrasi kerja sama, disiplin, bersih, ramah, dan respon pemberdayaan masyarakat pengguna jasa dalam memberikan pelayanan sesuai dengan tugas yang dibebankan kepadanya akan meminimalisir keluhan masyarakat pengguna jasa yang berimplikasi kepada terlaksananya program secara optimal.

Hasil wawancara tersebut bermakna bahwa dalam memberikan kepuasan masyarakat pengguna jasa pelayanan kesehatan ada lima aspek yang harus dilaksanakan oleh petugas dalam melaksanakan program yaitu kedisiplinan aparat birokrasi dalam menindaklanjuti keluhan masyarakat pengguna jasa, kekompakan aparat birokrasi dalam memberikan pelayanan kepada masyarakat pengguna jasa, kebersihan selalu dijaga oleh aparat birokrasi dalam merespon keluhan masyarakat pengguna jasa, keramahan aparat birokrasi dalam merespon keluhan masyarakat pengguna jasa, dan respon pemberdayaan masyarakat pengguna jasa. Kelima aspek tersebut apa bila ditindaklanjuti oleh petugas dalam memberikan layanan di berbagai sarana pelayanan kesehatan pemerintah akan mengurangi keluhan masyarakat pengguna jasa dalam mendapatkan layanan sehingga tujuan program dapat tercapai.

Aparat birokrasi yang responsif dapat mengatasi berbagai keluhan-keluhan masyarakat pengguna jasa terhadap pelayanan kesehatan gratis yang diberikan sehingga hal tersebut berimplikasi positif terhadap kepuasan masyarakat pengguna jasa yang pada akhirnya dapat meningkatkan derajat kesehatan masyarakat sehingga tujuan program dapat tercapai secara optimal.

Berdasarkan uraian temuan penelitian dan pembahasan di atas dapat direkonstruksikan ringkasan temuan penelitian, sehingga mempermudah alur pemikiran sebagaimana dapat dilihat pada tabel 1 . 
Basra, Model Responsivitas Birokrasi dalam Implementasi Kebijakan pelayanan kesehatan gratis $\mid 67$

Tabel 1 Ringkasan Temuan Penelitian tentang Model Responsivitas Birokrasi dalam Implementasi Kebijakan Pelayanan Kesehatan Gratis di Kabupaten Sidenreng Rappang.

\begin{tabular}{|c|c|c|c|}
\hline Fokus Penelitian & Kondisi Ideal & Temuan Penelitian & Sintesis \\
\hline $\begin{array}{l}\text { Model responsivitas } \\
\text { birokrasi dalam } \\
\text { implementasi } \\
\text { kebijakan } \\
\text { pelayanan } \\
\text { kesehatan gratis di } \\
\text { Kabupaten } \\
\text { Sidenreng Rappang. }\end{array}$ & $\begin{array}{lr}\text { Dilulio } & (1994) \\
\text { bahwa responsivitas } \\
\text { sangat diperlukan } \\
\text { dalam pelayanan } \\
\text { publik karena hal } \\
\text { tersebut merupakan } \\
\text { bukti kemampuan } \\
\text { organisasi untuk } \\
\text { mengenali } \\
\text { kebutuhan } \\
\text { masyarakat, } \\
\text { menyusun agenda } \\
\text { dan } \\
\text { pelayanan, } \\
\text { mengembangkan } \\
\text { program-program } \\
\text { pelayanan publik } \\
\text { sesuai ran dengan } \\
\text { kebutuhan r dan } \\
\text { aspirasi masyarakat. }\end{array}$ & 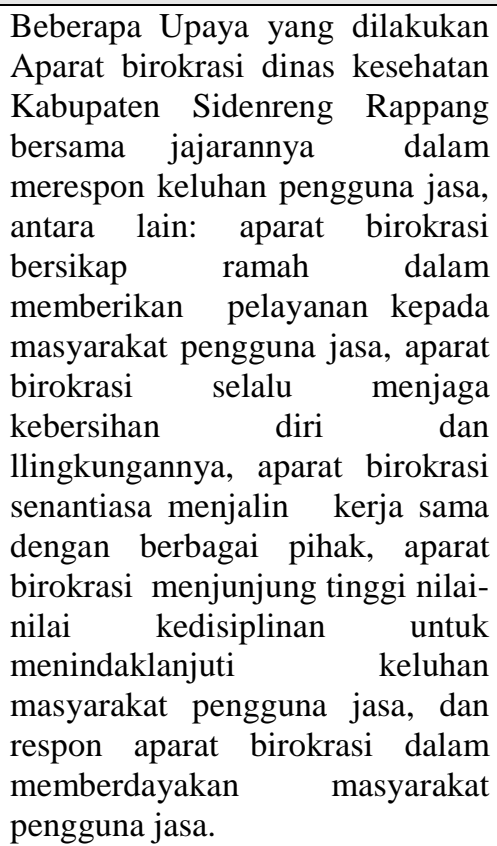 & $\begin{array}{l}\text { Keramahan, } \\
\text { kebersihan, kerja } \\
\text { sama, kedisiplinan, } \\
\text { dan respon aparat } \\
\text { birokrasi dalam } \\
\text { memberdayakan } \\
\text { masyarakat } \\
\text { pengguna jasa } \\
\text { merupakan model } \\
\text { pengembangan } \\
\text { beberapa indikator } \\
\text { terhadap } \\
\text { responsivitas aparat } \\
\text { birokrasi dalam } \\
\text { pelaksanaan } \\
\text { pelayanan publik. }\end{array}$ \\
\hline
\end{tabular}

Sumber: Hasil olah data penelitian, 2015

\section{PEMBAHASAN HASIL PENELITIAN}

Implementasi kebijakan pelayanan kesehatan gratis di Kabupaten Sidenreng Rappang sebagai tindak lanjut dari Peraturan Daerah Pemerintah Provinsi Sulawesi Selatan No. 13 tahun 2008 tentang Pedoman Pelayanan Kesehatan Gratis dan Peraturan Daerah Kabupaten Sidenreng Rappang Nomor 2 tahun 2009 tentang Penyelenggaraan Pelayanan Kesehatan Gratis. Pada bagian pertimbangan dari Perda Kabupaten Sidenreng Rappang Nomor 2 tahun 2009 tersebut, dengan jelas disebutkan pada pertimbangan No 20, yaitu Perda Pelayanan Kesehatan Gratis Kabupaten Sidenreng Rappang dibuat dengan mempertimbangkan Perda Pemerintahan Provinsi Sulawesi Selatan Nomor 2 tahun 2009 tentang perjanjian kerja sama Penyelenggaraan Pelayanan Kesehatan Gratis. 


\section{Proposisi dan alternatif model responsivitas birokrasi dalam implementasi kebijakan pelayanan kesehatan gratis di Kabupaten Sidenreng Rappang}

Tahapan implementasi kebijakan pelayanan kesehatan gratis di Kabupaten Sidenreng Rappang dilaksanakan sesuai ketentuan Peraturan Daerah No 02 tahun 2009 tentang Penyelenggaraan Pelayanan Kesehatan Gratis dengan tujuan untuk meningkatkan akses guna tercapainya derajat kesehatan masyarakat yang optimal, meningkatkan kualitas dan pemerataan untuk mendapatkan pelayanan, serta meringankan beban penduduk dalam pembiayaaan pelayanan. Sasaran pelayanan adalah seluruh masyarakat daerah yang tidak tercakup dalam Jaminan Kesmasehatan Masyarakat (JAMKESMAS), Asuransi Kesehatan (ASKES), Jaminan Sosial Tenaga Kerja (JAMSOSTEK), dan auransi kesehatan lainnya. Ruang lingkup pelayanan meliputi pelayanan dasar, pelayanan rujukan, dan kegawatdaruratan.

Implementor kebijakan pelayanan kesehatan gratis di Kabupaten Sidenreng Rappang adalah aparat birokrasi dinas kesehatan (instansi kesehatan), rumah sakit umum daerah, puskesmas, puskesmas pembantu (PUSTU), dan pos kesehatan desa (POSKESDES). Salah satu indikator keberhasilan implementasi kebijakan publik di bidang sosial budaya adalah kemampuan pemerintah daerah dalam membangun sektor pendidikan dan kesehatan masyarakat. Khusus pada sektor kesehatan masyarakat terdiri dari sarana dan prasarana kesehatan masyarakat, rumah sakit, puskesmas, tenaga medis, pelayanan kesehatan gratis, serta ketersediaan obat-obat generik, Rifdan (2013:55). Apa bila implementasi kebijakan di bidang kesehatan melalui program pelayanan kesehatan gratis dapat dilaksanakan secara konsisten, efektif, dan berkesinambungan, maka keluhan masyarakat pengguna jasa dapat diminimalisir karena masyarakat merasa puas atas pelayanan yang diberikan oleh aparat birokrasi dinas kesehatan dan segenap jajarannya.

Aparat birokrasi dinas kesehatan harus menciptakan iklim yang kondusif untuk meningkatkan pemberdayaan/keterlibatan melalui program partisipatif dari berbagai kelompok yang ada di masyarakat. Bahkan juga dalam mengalokasikan sumber daya dan dana tertentu, untuk menyelenggarakan fungsi tersebut, birokrasi pemerintah harus menjadi instrumen yang responsif, andal, tangguh, dan profesional.

Selama pelaksanaan implementasi kebijakan pelayanan kesehatan gratis di Kabupaten Sidenreng Rappang yang dimulai sejak tahun 2008 dan masih berlangsung sampai dengan sekarang tentu menemui kendala dan hambatan dalam proses penyelenggaraannya, baik hambatan yang diakibatkan oleh manajemen pengelolaan yaitu perencanaan, pelaksanaan, dan monitoring evaluasi, maupun hambatan yang disebabkan oleh kurangnnya responsivitas pemerintah pusat, propinsi, dan kabupaten kota dalam sistem pembiayaan kesehatan. Kendala dan hambata tersebut harus direspon dengan baik oleh aparat birokrasi dinas kesehatan melalui pelaksanaan program-program strategis, peningkatan partisipasi masyarakat pengguna jasa dalam proses pelayanan kesehatan, serta peningkatan pelayanan kesehatan yang efektif, efisien, dan berkualitas sehingga kendala dan hambatan tersebut bisa tertangani dengan baik yang berimplikasi positif dalam memenuhi harapan, keinginan, aspirasi maupun tuntutan masyarakat terhadap beberapa keluhan yang muncul dalam implementasi kebijakan pelayanan kesehatan gratis di Kabupaten Sidenreng Rappang. 
Basra, Model Responsivitas Birokrasi dalam Implementasi Kebijakan pelayanan kesehatan gratis $\mid 69$

Untuk merealisasikan harapan, keinginan, aspirasi maupun tuntutan masyarakat terhadap beberapa keluhan yang muncul, maka aparat birokrasi dinas kesehatan Kabupaten Sidenreng Rappang bersama dengan jajarannya harus berbena diri dengan melakukan beberapa upaya dalam merespon keluhan masyarakat pengguna jasa di berbagai tingkat pelayanan kesehatan yang ada, baik di rumah sakit umum daerah, puskesmas, puskesmas pembantu, maupun di pos kesehatan desa.

Berdasarkan fakta empirik yang terungkap pada hasil penelitian ini, maka upaya-upaya yang dilakukan oleh aparat birokrasi dinas kesehatan Kabupaten Sidenreng Rappang dalam memenuhi harapan, keinginan, aspirasi dan tuntutan masyarakat terhadap keluhan yang muncul selama penyelenggaraan pelayanan kesehatan gratis, yaitu selain aspek responsivitas birokrasi untuk melibatkan dan memberdayakan masyarakat pengguna jasa, maka aparat birokrasi dinas kesehatan Kabupaten Sidenreng Rappang melakukan upaya-upaya lain melalui pelaksanaan dan pemgembangan program-program pelayanan yang terdiri dari beberapa dimensi, yaitu:

a. Aparat birokrasi bersikap ramah dalam memberikan pelayanan kesehatan kepada masyarakat pengguna jasa.

Sikap ramah yang dilakukan oleh aparat birokrasi dalam merespon keluhan masyarakat pengguna jasa pelayanan kesehatan gratis dapat mencerminkan adanya tanggungjawab yang didasari integritas dalam pencapaian visi dan misi organisasi secara optimal, sehingga sikap merespon keluhan dapat dilakukan secara kolektif pada masing-masing tingkat tatanan pelayanan kesehatan. Pada prinsipnya meskipun dalam pelaksanaan implementasi kebijakan pelayanan kesehatan gratis masih banyak keluhan dari pengguna jasa, tetapi beberapa dari keluhan itu dapat direspon dengan baik oleh aparat birokrasi dengan cara menerima keluhan dengan ramah.

Menurut Heri Kuswara (2009) ramah adalah sikap santun terhadap semua orang agar orang lain merasakan kenyamanan dan perasaan senang saat bersama kita. Bersikap ramah dan baik ternyata belum cukup bagi aparat birokrasi dalam menjalankan tugasnya. Sikap dan perilaku aparat birokrasi menjadi salah satu indikator responsivitas pelayanan publik. sikap dan perilaku yang ramah, yaitu murah senyum, sapa, salam, sopan, dan santun. Sikap ramah seperti itu akan memecahkan kekakuan yang ada. Denga sikap pandai bergaul aparat birokrasi akan cepat akrab dengan masyarakat pengguna jasa sehingga keluhan dapat teratasi.

Keramahan aparat birokrasi erat kaitannya dengan kualitas pelayanan dan mempunyai pengaruh yang positif terhadap kepuasan masyarakat pengguna jasa. Dalam memberikan pelayanan aparat birokrasi yang berada di garis terdepan yang berinteraksi langsung dengan masyarakat pengguna jasa harus dapat memberikan sentuhan pribadi yang menyenangkan. Sentuhan pribadi yang menyenangkan tercermin melalui penampilan, bahasa tubuh dan tutur bahasa yang sopan, ramah, lincah, dan gesit. Aparat birokrasi yang selalu menunjukkan sikap ramah dalam memberikan pelayanan kesehatan dapat memberikan kepuasan pada masyarakat pengguna jasa karena harapan dan aspirasinya terpenuhi. Khususnya dalam merespon keluhan. 
b. Aparat birokrasi selalu menjaga kebersihan diri dan llingkungannya.

Kebersihan adalah keadaan bebas dari kotoran, termasuk di antaranya debu, sampah, dan bau. Kebersihan juga berarti bebas dari virus, bakteri patogen, dan bahan kimia yang berbahaya. Kebersihan adalah salah satu tanda dari keadaan hygiene yang baik. Aparat birokrasi dinas kesehatan Kabupaten Sidenreng Rappang perlu menjaga kebersihan diri dan lingkungan agar sehat, tidak berbau, tidak malu, tidak menyebabkan kotoran, atau menularkan kuman penyakit bagi diri sendiri maupun masyarakat pengguna jasa. Kebersihan badan meliputi kebersihan diri sendiri, seperti mandi, gosok gigi, mencuci tangan, dan memakai pakaian yang bersih. Mencuci adalah salah satu cara menjaga kebersihan dengan menggunakan air dan sejenis sabun atau detergen. Mencuci tangan dengan sabun atau menggunakan produk kebersihan tangan merupakan cara terbaik dalam penularan influensa dan batuk. Kebersihan lingkungan adalah kebersihan tempat tinggal, tempat bekerja, dan tempat masyarakat awam. Kebersihan tempat tinggal dilakukan dengan cara mengelap rumah dan perabotannya, menyapu dan mengepel lantai, mencuci peralatan masak dan peralatan makan, membersihkan kamar mandi dan wc, serta membuang sampah. Kebersihan lingkungan dilakukan dengan menjaga kebersihan halaman dan memebersihkan jalan di depan rumah, kantor, dari pada sampah atau kotoran. Tingkat kebersihan berbeda beda menurut tempat dan kegiatan yang dilakukan oleh aparat birokrasi. Contohnya, kebersihan di rumah berbeda dengan kebersihan ruang bedah di rumah sakit.

Menurut Poter Perry (2005) kebersihan merupakan suatu tindakan memelihara kebersihan dan kesehatan seseorang untuk kesejahteraan fisik dan psikis, kurang perawatan diri adalah kondisi dimana seseorang tidak mampu melakukan perawatan kebersihan untuk dirinya. Jika seseorang sakit, biasanya masalah kebersihan kurang di perhatikan. Hal ini terjadi karena menganggap masalah kebersihan adalah masalah sepele, padahal hal tersebut dibiarkan terus dapat mempengaruhi kesehatan secara umum. Karena itu hendaknya setiap aparat birokrasi selalu berusaha supaya personal hygiene dipelihara dan ditingkatkan. Kebersihan dan kerapian sangat penting dan diperlukan agar aparat birokrasi dapat hidup secara sehat. Jadi dalam hal ini sanitasi ditujukan kepada lingkungannya, sedangkan hygiene di tujukan kepada aparat birokrasinya.

Sanitasi lingkungan yang sehat serta didukung oleh aparat birokrasi dinas kesehatan Kabupaten Sidenreng Rappang yang senantiasa memelihara kebersihan, baik kebersihan diri aparat birokrasi itu sendiri maupun kebersihan lingkungan sarana pelayanan kesehatan yang ada, akan memeberikan kepercayaan diri aparat birokrasi dalam melaksanakan tugas terkait dengan responsivitas birokrasi dalam implementasi kebijakan pelayanan kesehata gratis sehingga kegiatan dapat dilaksanakan secara optimal sesuai dengan harapan masyarakat pengguna jasa yang berimplikasi pada kepuasan masyarakat. Tanda-tanda orang yang beriman adalah orang yang selalu menjaga kebersihan.

c. Aparat birokrasi senantiasa menjalin kerja sama dengan berbagai pihak.

Kekompakan kelompok bukanlah senjata rahasia dalam pencarian untuk peningkatan kinerja kelompok atau tim. Caranya agar berhasil adalah dengan menjaga agar ukuran 
Basra, Model Responsivitas Birokrasi dalam Implementasi Kebijakan pelayanan kesehatan gratis $\mid 71$

kelompok-kelompok tugas tetap kecil, meyakinkan standar-standar kinerja dan sasaran-sasaran harus jelas dan dapat diterima, mencapai beberapa keberhasilan awal dan mengikuti petunjukpetunjuk praktis. Tim kerja yang dipilih sendiri di mana orang-orang mengangkat teman satu timnya sendiri dan cara-cara sosial selepas kerja dapat merangsang kekompakan sosioemosional. Membantu perkembangan kekompakan sosio-emosional perlu diseimbangkan dengan kekompakan tim.

Menurut West (2002), bahwa ada 5 (lima) hal yang bisa menjadi bahan latihan kekompakan dalam sebuah tim, yaitu:

1) Komunikasi, meliputi kelancaran komunikasi, tepat dan akurat menyampaikan informasi, dan saling terbuka.

2) Respek satu sama lain, meliputi memahami kebutuhan dan mendengarkan pendapat pihak lain, memberikan feedback konstruktif, serta member apresiasi.

3) Kesiapan menerima tantangan, juga kegigihan dan ketekunan dalam bekerja.

4) Kerja sama, meliputi kemampuan memahami pentingnya komitmen, kepercayaan, penyelesaian masalah bersama, kejelasan tujuan, memberi dukungan dan motivasi, serta mengakui kesuksesan.

5) Kepemimpinan, baik memimpin orang lain, tim, maupun memimpin diri sendiri.

Pada prinsifnya bahwa team work harus dibangun atas dasar kekompakan yang utuh.

Kekompakan ditandai dengan kuatnya hubungan antar anggota tim yang saling merasakan adanya ketergantungan dalam urutan tugas, ketergantungan hasil yang ingin dicapai dan komitmen yang tinggi sebagai bagian dari sebuah tim. Kekompakan kelompok terbentuk karena adanya daya tarik antar anggota kelompok atau kelompok itu sendiri. Pada beberapa kelompok, ikatan diantara anggota-anggota kuat dan menetap. Pada kelompok lain ikatan tersebut merenggang, dengan hilangnya rasa "berkelompok" dan semakin lama anggotaanggotanya cenderung memisahkan diri.

Berdasarkan analisis fakta empirik yang terungkap dalam penelitian ini, bahwa aparat birokrasi dinas ksehatan Kabupaten Sidenreng Rappang selalu menjaga kerja sama dalam melaksanakan tugas termasuk pelaksanaan kegiatan yang berhubungan dengan responsivitas birokrasi dalam implementasi kebijakan pelayanan kesehatan gratis di berbagai sarana pelayanan kesehatan yang ada.

Kerja sama yang ditunjukkan oleh aparat birokrasi dalam memberikan pelayanan kepada masyarakat pengguna jasa, berupa kerja sama lintas program misalnya kasus balita gizi buruk ditangani oleh petugas gizi yang bekerja sama dengan dokter dan bidan desa. Kerja sama yang lain yaitu kerja sama lintas sektor, kerja sama lintas sektor sehubungan dengan program pelaksanaan kegiatan yang memerlukan keterlibatan sektor terkait misalnya, peningkatan sumber daya manusia aparatur birokrasi dilakukan kerja sama dengan institusi pendidikan seperti yang dilakukan dinas kesehatan Kabupaten Sidenreng Rappang bekerja sama dengan STIKES Muhammadiyah Sidrap dalam mendidik aparat birokrasi yaitu tenaga bidan dan perawat melalui pendidikan yang berkelangjutan.

Bentuk kerja sama yang lain yaitu bekerja sama dengan dinas pekerjaan umum dalam rangka pemeliharaan dan pengadaan sarana kesehatan, seperti rumah sakit, puskesmas, pukesmas pembantu, dan pos kesehatan desa. Dan masih banyak lagi bentuk kerja sama dengan 
sektor-sektor terkait yang tidak dapat disebutkan satu-persatu. Sehingga dapat dirumuskan bahwa kerja sama yang efektif dengan lintas program dan lintas sektor dapat mengoptimalisasi penyelenggaraan implementasi kebijakan pelayanan kesehatan gratis.

d. Aparat birokrasi menjunjung tinggi nilai-nilai kedisiplinan untuk menindaklanjuti keluhan masyarakat pengguna jasa.

Kedisiplinan merupakan salah satu aspek yang dapat menentukan keberhasilan sebuah program, termasuk dalam program pelayanan kesehatan gratis di Kabupaten Sidenreng Rappang yang terlaksana sejak tahun 2008 sampai dengan sekarang, sehingga kedisiplinan menjadi salah satu kunci terhadap pelaksanaan pelayanan kesehatan gratis. Kedisiplinan ini tidak hanya dilakukan oleh aparat birokrasi dinas kesehatan di berbagai tingkat pelayanan kesehatan yang ada, namun juga masyarakat pengguna jasa sebagai sasaran program pelayanan kesehatan gratis. Kedisiplinan makin penting dalam mewujudkan reformasi birokrasi pelayanan publik dalam merespon keluhan masyarakat pengguna jasa pelayanan yang terkadang beberapa aparat masih menimbulkan banyak kebingunan tata laksana maupun pelayanan kesehatan gratis. Disiplin adalah kepatuhan kita terhadap peraturan yang berlaku. Kepatuhan ini sangat penting dalam era reformasi birokrasi pelayanan publik, sehingga pengaturan teknis dan petunjuk pelaksanaan bisa terlaksana dengan efektif.

Kepatuhan aparat birokrasi dan masyarakat pengguna jasa pada pengaturan teknis penyelanggaraan pelayanan kesehatan gratis, diharapkan kebingungan yang masih ada di lapangan bisa sedikit teratasi. Hal ini disebabkan oleh karena pemahaman mekanisme penyelenggaraan program pelayanan kesehatan gratis perlahan-lahan menjadi sama, antara aparat birokrasi dinas kesehetan sebagai implementor kebijakan dan masyarakat pengguna jasa sebagai sasaran program pelayanan kesehatan gratis. Peneliti tidak menampik, permasalahan program pelayanan kesehatan gratis di Kabupaten Sidenreng Rappang berakar pada pemahaman masyarakat pengguna jasa dan aparat birokrasi dinas kesehatan pelaksana program yang belum sama. Mekanisme penyelenggaraan pelayanan kesehatan gratis dianggap sama dengan asuransi terdahulu yaitu asuransi kesehatan masyarakat miskin (ASKESKIN) dan jaminan pemeliharaan kesehatan masyarakat (JAMKESMAS). Padahal jelas setiap asuransi tersbut berbeda dalam pelaksanannya sesuai dengan aturan yang ada.

Kondisi ini juga merupakan dampak minimnya sosialisasi sebelum pelaksanaan program pelayanan kesehatan gratis karena waktu sosialisai yang tersedia memang sangat minim, akibatnya tidak bisa mencakup seluruh komponen masyarakat. Sosialisasi ini harus terus dibantu sesama anggota masyarakat. Sosialisasi dan kedisiplinan tentu akan berdampak positif terhadap pelaksanaan program pelayanan kesehatan gratis.

Lebih jauh, peneliti yakin program pelayanan kesehatan gratis disusun untuk kepentingan masyarakat. Program pelayanan kesehatan gratis akan meningkatkan derajat kesehatan masyarakat, dengan perlahan mengedepankan upaya promotif dan upaya preventif. Tentunya tidak melupakan upaya kuratif dan rehabilitatif, sehingga masyarakat pengguna jasa mendapatkan pelayanan kesehatan gratis yang komprehensif. 
Basra, Model Responsivitas Birokrasi dalam Implementasi Kebijakan pelayanan kesehatan gratis $\mid 73$

Meski menemui banyak kendala dan hambatan, pada akhirnya masyarakat pengguna jasa akan semakin memahami program pelayanan kesehatan gratis. Aparat birokrasi akan selalu melakukan pembenahan, pelayanan, dan pembinaaan yang menuju ke arah perbaikan sesuai dengan dukungan sarana dan prasarana yang tersedia sebagai perwujudan dari nilai-nilai yang terkandung dalam kedisiplinan. Aparat birokrasi yang menjujung tinggi nilai-nilai kedisiplinan dapat mengurangi keluhan masyarakat pengguna jasa khususnya terhadap jam pelayanan, jika petugas datang lebih awal maka masyarakat yang membutuhkan pelayanan yang cepat, tepat, cermat, dengan waktu yang tepat tidak akan menunggu, hal tersebut berimplikasi positif pada kualitas pelayanan, sehingga masyarakat pengguna jasa akan merasa puas karena dilayani atau direspon dengan cepat dengan waktu yang tepat.

Argumentasi tersebuat relevan dengan pendapat dari Zaithamal dkk (1990) yang menyatakan dimensi Responsiviness (respon/ketanggapan), indikatornya yaitu:

a) Merespon setiap pelanggan/pemohon yang ingin mendapatkan pelayanan;

b) Petugas/aparatur melakukan pelayanan dengan cepat;

c) Petugas/aparatur melakukan pelayanan dengan tepat;

d) Petugas/aparatur melakukan pelayanan dengan cermat;

e) Petugas/aparatur melakukan pelayanan dengan waktu yang tepat;

f) Semua keluhan pelanggan direspon oleh petugas.

Penerapan responsivitas aparat birokrasi dinas kesehatan dengan ramah, bersih, kerja sama, dan disiplin, serta respon terhadap pemberdayaan/melibatkan masyarakat dalam implementasi kebijakan pelayanan kesehata gratis yang efektif dapat mengatasi keluhan masyarakat pengguna jasa sehingga tujuan pelayanan kesehatan gratis dapat dicapai secara optimal.

Berdasarkan konsep John Dilulio yang menyatakan bahwa responsivitas sangat diperlukan dalam pelayanan publik karena hal tersebut merupakan bukti kemampuan organisasi untuk mengenali kebutuhan masyarakat, menyusun agenda dan prioritas pelayanan serta mengembangkan program-program pelayanan publik sesuai dengan kebutuhan dan aspirasi masyarakat.

Konsep responsivitas dalam pelayanan publik kemudian diteliti oleh peneliti yang lain yaitu Dwiyanto, hasil penelitiannya menjelaskan bahwa di dalam operasionalisasinya mengembangkan beberapa indikator responsivitas pelayanan publik, yaitu: keluhan pengguna jasa, sikap aparat birokrasi dalam merespon keluhan pengguna jasa, penggunaan keluhan pengguna jasa sebagai referensi perbaikan layanan publik, berbagai tindakan aparat birokrasi dalam memberikan pelayanan, dan penempatan pengguna jasa oleh aparat birokrasi dalam sistem pelayanan.

Berdasarkan hasil penelitian ini ditemukan pula bahwa model responsivitas birokrasi dalam implementasi kebijakan pelayanan kesehatan gratis di Kabupaten Sidenreng Rappang dikonstruksikan dalam lima dimensi yaitu sikap ramah, bersih, kerja sama tim, disiplin tindakan, dan pemberdayaan masyarakat pengguna jasa. Sehingga dengan demikian dapat dirumuskan sebuah proposisi sebagai berikut:

Proposisi : Alternatif model responsivitas birokrasi pada implementasi kebijakan pelayanan kesehatan gratis dilaksanakan dengan mengefektifkan beberapa dimensi, yaitu 
dimensi keramahan aparat birokrasi, dimensi kebersihan aparat birokrasi, dimensi kerjasama aparat birokrasi, dimensi kedisiplinan aparat birokrasi serta dimensi pemberdayaan masyarakat pengguna jasa.

Pada prinsipnya proposisi dan alternatif model responsivitas birokrasi dalam implementasi kebijakan pelayanan kesehatan yang diselenggarakan oleh aparat birokrasi dinas kesehatan Kabupaten Sidenreng Rappang sebagai implementor kebijakan, baik di rumah sakit umum daerah, puskesmas, puskesmas pembantu, maupun di pos kesehatan desa melalui kegiatan program strategis yang telah direncanakan sebelumnya, merupakan upaya-upaya aparat birokrasi untuk merespon keluhan masyarakat pengguna jasa sebagai sasaran kebijakan.

Proposisi ini merupakan proposisi dan alternatif model pengembangan indikator responsivitas pelayanan publik yang telah ditemukan oleh beberapa peneliti sebelumnya, terkhusus pada responsivitas birokrasi dalam implementasi kebijakan pelayanan kesehatan gratis di Kabupaten Sidenreng Rappang.

Hasil temuan dalam penelitian ini berimplikasi positif dan mendukung teori Jhon Dilulio tentang responsivitas pelayanan publik yang menyatakan bahwa responsivitas sangat diperlukan dalam pelayanan publik karena hal tersebut merupakan bukti kemampuan organisasi untuk mengenali kebutuhan masyarakat, menyusun agenda dan prioritas pelayanan serta mengembangkan program-program pelayanan publik sesuai dengan kebutuhan dan aspirasi masyarakat.

Selain itu, jika ditinjau dari sudut pandang teori managemen organisasi, hasil penelitian ini juga melengkapi teori yang dikemukakan oleh Henry Mintzberg tentang elemen organisasi bahwa elemen yang menyatakan managemen puncak yang memberikan taggungjawab seluruh organisasi, yang disebut dengan peran antarpribadi dan peran informasional terkhusus pada responsivitas birokrasi dalam implementasi kebijakan pelayanan kesehatan gratis di Kabupaten Sidenreng Rappang.

Berdasarkan penjelasan hasil penelitian ini dan merujuk pada konsep dan fakta-fakta yang telah dikemukakan, maka model responsivitas dalam implementasi kebijakan pelayanan kesehatan gratis di Kabupaten Sidenreng Rappang dapat dilihat pada kerangka proposisi dan alternatif model responsivitas birokrasi dalam implementasi kebijakan pelayanan kesehatan gratis di Kabupaten Sidenreng Rappang yang secara visual dapat dirumuskan pada gambar 1. 


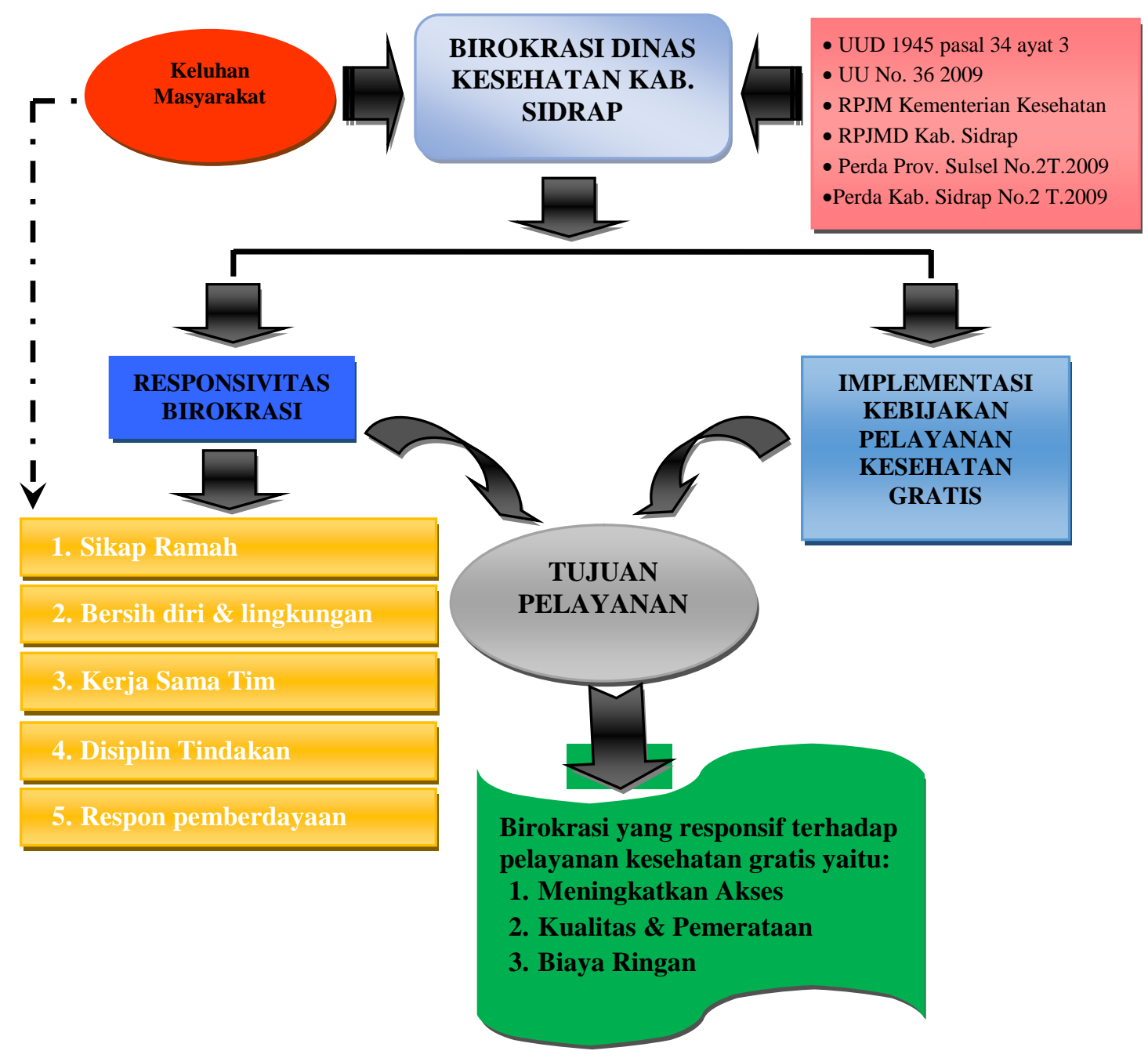

Gambar 1 Kerangka proposisi dan alternatif model responsivitas birokrasi dalam implementasi kebijakan pelayanan kesehatan gratis.

\section{PENUTUP}

Proposisi dan alternatif model responsivitas birokrasi dalam implementasi kebijakan pelayanan kesehatan gratis di Kabupaten Sidenreng Rappang dengan melalui beberapa dimensi yang menjadi pengembangan indikator responsivitas pelayanan publik, yaitu keramahan aparat 
birokrasi dalam merespon keluhan masyarakat pengguna jasa, kebersihan selalu dijaga oleh aparat birokrasi dalam merespon keluhan masyarakat pengguna jasa, kerjasama aparat birokrasi dalam memberikan pelayanan kepada masyarakat pengguna jasa, kedisiplinan aparat birokrasi dalam menindaklanjuti keluhan masyarakat pengguna jasa, serta respon aparat birokrasi dalam memberdayakan masyarakat pengguna jasa dengan pelaksanaan kegiatan yang responsif.

\section{DAFTAR PUSTAKA}

Ahmad, Jamaluddin. 2011. Perilaku Birokrasi dan Pengambilan Keputusan. Makassar: Badan Penerbit Universitas Negeri Makassar.

Akib, Haedar. 2010. Implementasi Kebijakan: Apa, Mengapa, dan Bagaimana?, Jurnal Administrasi Publik, Program Pascasarjana UNM Makassar. Volume 1 No. 1; Makassar.

Beetham, David. 1990. Bureaucrasy, diterjemahkan oleh Saliat Simamora, Jakarta: Bumi Aksara.

Blau, Peter M. dan Meyer Marshall W. 2000. Bureacracy in Modern Society, Jakarta: Prestasi Pustakarya.

Dilulio, Jhon J. (ed.). 1994. Deregulating the Public Service: Can Government be Improved?. Washingtong D.C.: The Brookings Institution.

Dwiyanto, Agus. 2008. Reformasi Birokrasi Publik Indonesia. Yogyakarta: Gajah Mada University Press.

Kausar, AS. 2009. Sistem Birokrasi Pemerintahan di Daerah dalam Bayang-Bayang Budaya Patron-Klien. Bandung: PT. Alumni

Miftah, Thoha. 2003. Birokrasi dan Politik Indonesia. PT Raja Grafindo Persada. Jakarta.

Rakhmat. 2009. Teori Administrasi dan Menajement Publik, Jakarta: Pustaka Arf.

Rozi, Syafuan. 2006. Zaman Bergerak Birokrasi Dirombak Potret Birokrasi dan Politik di Indonesia. Jakarta: Pustaka Pelajar.

Said, M.M. 2007. Birokrasi di Negara Birokratis. Malang: UPT. Penerbitan Universitas Muhammadiyah Malang.

Siagian, Sondang P. 2000. Teori Pengembangan Organisasi. Jakarta: Bumi Aksara.

Van Meter, Donald. and Van Horn, Carl. 1975. "The Policy Implementation Process: Aconceptual Frame", Administration and Society, 6:445-88 dalam Parson, Wayne. 2001 Public Policy. Pengantar Teori dan Praktik Analisis Kebijakan. Kencana Prenada Media Group.

Widodo.J. 2002. Akuntabilitas dan Kontrol Birokrasi. Surabaya: Insan Cendekia.

Zaithamal, Valarie A., Parasuraman \& Berry, L. 1990. Delivering Quality Services Balancing Custumer Perceptions and Expectations. New York: The Free Press.

Peraturan Bupati Sidenreng Rappang Nomor 68 tahun 2008 tentang "Pedoman Pelaksanaan Program Pelayanan Kesehatan Gratis di Kabupaten Sidenreng Rappang”

Peraturan Daerah Kabupaten Sidenreng Rappang Nomor 02 tahun 2009, Tentang Penyelenggaraan Pelayanan Kesehatan Gratis. 
Basra, Model Responsivitas Birokrasi dalam Implementasi Kebijakan pelayanan kesehatan gratis |77

Peraturan Daerah Provinsi Sulawesi Selatan Nomor 2 tahun 2009, tentang Kerjasama Penyelenggaraan Pelayanan Kesehatan Gratis.

Peraturan Gubernur Provinsi Sulawesi Selatan Nomor 13 tahun 2008 tentang Pedoman Pelayanan Kesehatan Gratis.

Profil Kesehatan Kabupaten Sidenreng Rappang. 2013. Pangkajene: Dinas Kesehatan. 